\title{
Investigation of Q Fever in Kilis and Shamil goats by ELISA and Touchdown-PCR
}

\author{
Elçin GÜNAYDIN ${ }^{1}$, Selçuk PEKKAYA ${ }^{2}$, H. Kaan MÜŞTAK ${ }^{3}$, Bestami DALKILIÇ ${ }^{4}$ \\ ${ }^{1}$ Veterinary Control Central Research Institute, Breeding Disease Laboratory, Etlik, Ankara; ${ }^{2}$ Veterinary Control Central Research \\ Institute, Biochemistry Laboratory, Etlik, Ankara; ${ }^{3}$ Ankara University Faculty of Veterinary Medicine, Department of Microbiology, \\ Dışkap1, Ankara; ${ }^{4}$ University of Gaziantep, Vocational School of Higher Education, Gaziantep, Turkey.
}

Summary: This study was carried out on Kilis and Shamil goats to determine the different stages of Q fever-chronic and acute- in serum samples by indirect ELISA and in blood samples by touchdown-PCR, respectively. A total of 92 serum samples comprising 46 Kilis and 46 Shamil goats was examined and 7.60\%, 4.34\% and 10.8\% seropositivity were determined for total serum samples, Kilis and Shamil goat serum samples, respectively. Of the examined 92 blood samples belonging to 46 Kilis and 46 Shamil goats, none of them yielded 687 bp PCR products by touchdown-PCR. The positive ELISA titers were thought to be the evidence of previous infection. The province of Kilis localized in South-East Anatolian Region of Turkey was decided to be a risky region for Q fever.

Key words: Q fever, goat, ELISA, touchdown-PCR

\section{Kilis ve Halep keçilerinde ELISA ve Touchdown-PCR ile Q Humması'nın araştırılması}

Özet: Bu çalışma, Kilis ve Halep keçilerinde, Q Humması'nın farklı dönemlerini -kronik ve akut- sırasıyla; serum örneklerinde indirek ELISA, kan örneklerinde touchdown-PCR ile ortaya koymak için planlanmıştır. Kırkaltı Kilis ve 46 Halep keçisinden oluşan toplam 92 serum örneği incelendi ve toplam serum örnekleri, Kilis ve Halep keçi serumlarında seropoziflik sırasıly, 7.60\%, 4.34\% ve $10.8 \%$ bulundu. Kırkaltı Kilis ve 46 Halep keçisine ait toplam 92 kan örneğinin, hiçbirinde touchdown-PCR ile 687 bp'lık PCR ürünü tespit edilmedi. Pozitif ELISA titrelerinin daha once geçirilen infeksiyona kanıt olduğu düşünüldü. Türkiye'de Güneydoğu Anadolu Bölgesi’nde lokalize olan Kilis ilinin Q fever yönünden riskli bir bölge olduğuna karar verildi.

Anahtar sözcükler: Q humması, keçi, ELISA, touchdown-PCR

\section{Introduction}

Coxiella burnetii, an obligate intracellular bacterium, expressing phase variation related to the changes in lipopolysaccharide (LPS) is the causative agent of a zoonotic Q fever. Q fever is endemic throughout the world, occurring in diverse geographic regions and climatic zones (38). Ruminants, especially goat and sheep are the main reservoirs of $\mathrm{Q}$ fever and females may shed particles via vaginal secretions, faeces urine, and milk $(2,5,6,7)$.

C. burnetii infection is still considered to be a common cause of caprine abortion in several countries. Susceptible pregnant females develop necrotizing placentitis which results in abortion, whereas non-pregnant females do not develop clinical signs. After the initial abortions or infections, animals become immune to abortion but can remain subclinically infected. After the infection, the female can carry the organism indefinitely and sporadically shedding it with milk and at parturition (9). While acute $\mathrm{Q}$ fever infection occurs, antibodies against phase II antigens are observed in higher rates. In chronic infections, antibodies against both phase I and phase II antigens are found to be in higher rates because of the fact that $C$. burnetii is a phase variable bacterium (26).

Investigations on $\mathrm{Q}$ fever mostly depend on serological examinations such as immunofluorescence, complement fixation test (CFT) and ELISA (28). The ELISA detects anti-phase I and anti-phase II antibodies whereas IFA detects only anti-phase II antibodies. Rousset et al. (28), declared that when the serum samples were measured for both $\operatorname{IgM}$ and $\operatorname{IgG}$ antibodies against either phase I and phase II antigens. Anti-phase II antibodies predominated after the primary infections and persist throughout the course of the infection, whereas higher titers of antibodies to the phase I antigen present only the chronic form of the illness. CFT, on the contrary to ELISA, is in capable of detecting all IgG subclasses. In ruminants, only $\operatorname{IgG} 1$ fixes the complement and can thus be detected by CFT. Moreover, IgG2, IgM and anticomplement substances potentially present in serum are capable of interfering with fixation of IgG1 to the complement, lowering the titer of IgG1 detected by CFT 
(27). Rousset et al. (28), advised not to use CFT for serological animal screening because of its low sensitivity. Therefore, due to in capabilities of FAT and CFT mentioned above, ELISA is preferred in order to detect anti-phase I and phase II antibodies. However, seroconversion typically occurs $7-15$ days after symptoms appear. For a definitive diagnosis in the early stages of acute Q fever, serologic testing in combination with PCR is recommended (34). Touchdown-PCR employs an initial annealing temperature above the projected melting temperature $(\mathrm{T}(\mathrm{m}))$ of the primers being used, then progressively transitions to a lower, more permissive annealing temperature over the course of successive cycles, consequently, the primers avoid amplifying nonspecific sequences and the specifity enhanced.

The purpose of this study was to investigate the different stages -chronic and acute- of the infection in female non-pregnant goats. For this purpose, serum and blood samples of Kilis and Shamil goats reared in the province of Kilis localized in South-East Anatolian Region of Turkey were examined by indirect ELISA and touchdown-PCR, respectively.

\section{Material and Method}

Serum and Blood Samples: In May 2012, total 92 serum samples (46 Kilis, 46 Shamil goats) and 92 blood samples (46 Kilis, 46 Shamil goats) were collected from the province of Kilis, Turkey. All the goats were 2-3 years old female, non-pregnant, selected randomly and none of them have a recorded abortion history or reproductive disorder. The samples were collected from each 8 different herds (Kilis and Shamil goats were collected ranging between 3 to 9 goats and 2 to 13 goats, from each herd respectively). Blood samples collected in blood tubes with EDTA anticoagulant for touchdownPCR. All the sera for ELISA were separated 24 hours after sampling. All serum and blood samples were stored at $-20^{\circ} \mathrm{C}$ in deepfreeze until tested.

ELISA: The serum samples were tested for the presence of antibodies directed to both phase I and phase II antigens of $C$. burnetii using ELISA CHECKIT Qfever test (Idexx Laboratories, Broomfield, CO, USA) according to the manufacturer's instructions. Sera were prepared at 1:400 dilutions and specific antibodies were measured using a peroxidase-labeled anti-ruminant immunglobulin $\mathrm{G}$ conjugate. Results were expressed as a percentage of the optical density reading of the test sample (OD \%) calculated as $\mathrm{S} / \mathrm{P} \%=100 \mathrm{X}(\mathrm{S}-\mathrm{N}) /(\mathrm{P}-\mathrm{N})$ where $\mathrm{S}, \mathrm{N}$ and $\mathrm{P}$ are the $\mathrm{OD}$ values of the test sample, the negative and positive controls, respectively. The OD of the positive control should not exceed 2.000 and OD of negative control should not exceed 0.500. The difference between the positive and negative control should be $\geq 0.300$. The serum samples were read at 450 $\mathrm{nm}$ as reported in the kit instructions. The interpretaion of the results is as follows; $\mathrm{S} / \mathrm{P} \%<30$ is negative; $\mathrm{S} / \mathrm{P} \%$ $\geq 30$ and $<40$ is suspected; $\mathrm{S} / \mathrm{P} \% \geq 40 \%$ is positive.

Positive control in touchdown-PCR: DNA extracted from the phase II stage of $C$. burnetii in cell culture was kindly obtained from University of Firat, Faculty of Veterinary Medicine, Department of Microbiology and used as a positive control in touchdown-PCR.

The detection limit of touchdown-PCR with DNA extracted from phase II stage of C. burnetii: The initial concentration of DNA (undiluted DNA from phase II stage of $C$. burnetii obtained from cell culture) was measured as $5 \mathrm{ng} / \mu \mathrm{l}$ by spectrophotometer (Nanodrop $1000)$. Ten fold dilution of the stock DNA was done from $10^{-1}$ to $10^{-5}(5 \mathrm{ng} / \mu \mathrm{l}$ to $0.0005 \mathrm{ng} / \mu \mathrm{l})$. Each dilution was served as a template in touchdown-PCR.

DNA extraction: DNA was extracted from the blood samples by a commercial DNA isolation kit (QIAamp DNA Mini Kit; Qiagen, Cat no: 51104) according to the manufacturer's instructions. DNAs were stored at $-20^{\circ} \mathrm{C}$ until used.

Primers: Trans-1 and trans-2 primers, complementary to the IS1111 fragment, a transposon-like repetitive region were used for the diagnosis of $C$. burnetii by touchdown PCR. Primers as previously described by Hoover et al. (1992), (15) consisted of the following sequences: Trans 1; 5'-TAT GTA TCC ACC GTA GCC AGT C-3' and Trans-2; 5'-CCC AAC AAC ACC TCC TTA TTC-3'. Expected amplicon size was 687 bp.

Touchdown-PCR: Each reaction had a volume of 25 $\mu 1$ including, $22 \mu 1$ reaction mixture consisting of $2.5 \mu \mathrm{l}$ $10 \times$ PCR buffer (without $\left.\mathrm{MgCl}_{2}\right), 0.5 \mu \mathrm{dNTP}(10 \mathrm{mM})$, $1.5 \mu \mathrm{MgCl}_{2}(25 \mathrm{mM}), 1 \mu \mathrm{l}$ of each primer $(10 \mathrm{pmol} / \mu \mathrm{l})$, $0.25 \mu \mathrm{l}$ Taq DNA polymerase (5 U/ $\mu \mathrm{l})$ (Fermantas; EP 402), $15.25 \mu 1$ deionized water and $3 \mu$ template. Cycling parameters were as follows: initial denaturation at $95^{\circ} \mathrm{C}$ for 2 min followed by 5 cycles of denaturation at $94^{\circ} \mathrm{C}$ for $30 \mathrm{sec}, 66$ to $61^{\circ} \mathrm{C}$ (the temperature was decreased by $1^{\circ} \mathrm{C}$ between consecutive steps) for $1 \mathrm{~min}$, extension $72^{\circ} \mathrm{C}$ for $1 \mathrm{~min}$ and final extension $72^{\circ} \mathrm{C}$ for 10 min. Touchdown PCR was performed using Thermal Cycler (Arktik, ThermoScientific). PCR products were electrophoresed on a $1.5 \%$ agarose gel in TBE buffer containing $0.5 \mu / \mathrm{ml}$ of ethidium bromide at $100 \mathrm{~V}$ for 45 min and visualized under UV light.

\section{Results}

The sensitivity of touchdown-PCR: The detection limit of touchdown-PCR was determined as $0.005 \mathrm{ng} / \mu \mathrm{l}$ (Fig 1).

ELISA results of field samples: Seven (7.60\%) out of 92 serum samples were found to be antibody positive. Out of 46 serum samples belonging to Kilis goats, 2 (4.34\%) antibody positivities were determined. Of the examined 46 Shamil goat serum samples, positive ELISA titers were determined in $5(10.8 \%)$ serum samples. The 
positive titers were mentioned in Table $1 . \mathrm{S} / \mathrm{P} \%$ were calculated and interpretated according to the kit instructions.

Touchdown-PCR results of field samples: Of the examined 92 blood samples comprising 46 Kilis and 46 Shamil goats, none of them yielded $687 \mathrm{bp}$ amplification products by touchdown-PCR.

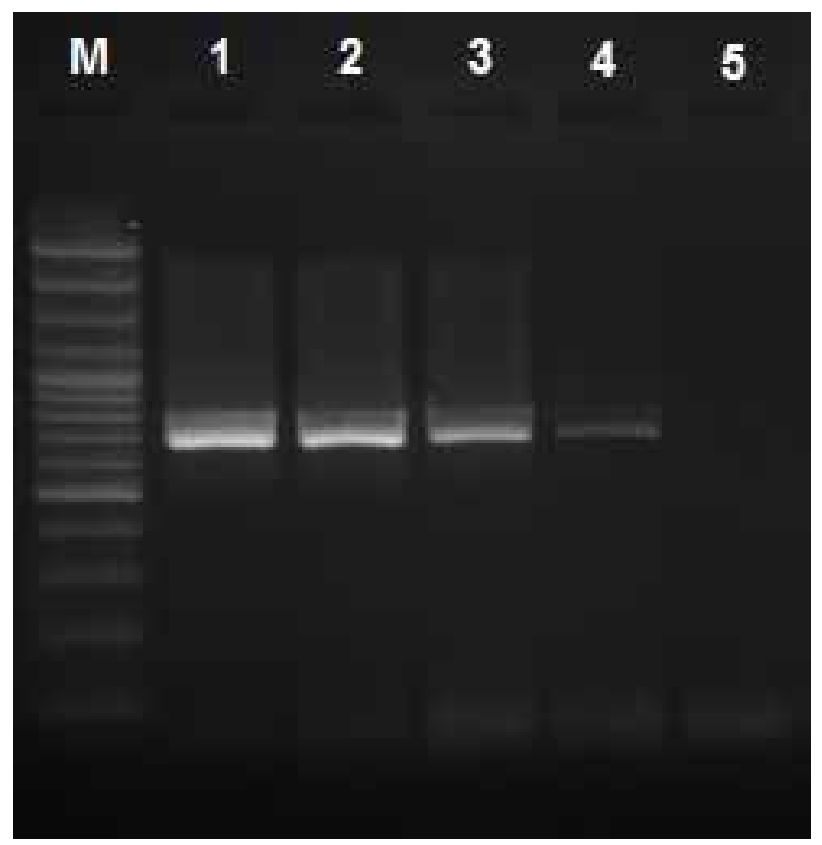

Figure 1 . The sensitivity of touchdown-PCR.

M: 100 bp DNA marker (Fermentas; O'RangeRuler 100 bp DNA Ladder, \# SM0623); Lane 1: $5 \mathrm{ng} / \mu 1$ (initial concentration of DNA), Lane 2: $5 \times 10^{-1} \mathrm{ng} / \mu \mathrm{l}$; Lane 3: $5 \times 10^{-2} \mathrm{ng} / \mu \mathrm{l}$; Lane 4: $5 \times 10^{-3} \mathrm{ng} / \mu \mathrm{l}$; Lane $5: 5 \times 10^{-4} \mathrm{ng} / \mu 1$

Şekil 1: Touchdown-PCR'ın sensitivitesi.

M: 100 bp DNA marker (Fermentas; O'RangeRuler 100 bp DNA Ladder, \# SM0623); Sıra 1: $5 \mathrm{ng} / \mu 1$ (başlangıç konsantrasyonu), Sira 2: $5 \times 10^{-1} \mathrm{ng} / \mu \mathrm{l}$; Sira 3: $5 \times 10^{-2} \mathrm{ng} / \mu \mathrm{l}$; Sira 4: $5 \times 10^{-3} \mathrm{ng} / \mu \mathrm{l}$; Sira $5: 5 \times 10^{-4} \mathrm{ng} / \mu 1$

Table 1. The positive ELISA titers (OD) and S/P \% values. Tablo1. Pozitif ELISA titreleri (OD) and S/P \% değerleri.

\begin{tabular}{ccc}
\hline $\begin{array}{c}\text { Code of ELISA } \\
\text { positive serum } \\
\text { samples }\end{array}$ & $\begin{array}{c}\text { Positive ELISA } \\
\text { Titers (OD) at } \\
\mathrm{A}_{450}\end{array}$ & $\begin{array}{c}\text { S/P \% of } \\
\text { positive serum } \\
\text { samples }\end{array}$ \\
\hline $\mathrm{K}^{*} 16$ & 1.571 & 76.4 \\
$\mathrm{~K} 33$ & 1.170 & 54.4 \\
$\mathrm{~S}^{*} 5$ & 1.203 & 56.2 \\
$\mathrm{~S} 25$ & 2.619 & 134.10 \\
$\mathrm{~S} 28$ & 1.142 & 52.86 \\
$\mathrm{~S} 38$ & 1.649 & 80.74 \\
$\mathrm{~S} 46$ & 1.161 & 53.90 \\
\hline
\end{tabular}

Minimum titer (OD) at $\mathrm{A}_{450}: 0.046$ and $\mathrm{S} / \mathrm{P} \%=-7.42$ (Negative) Maximum titer (OD) at $\mathrm{A}_{450}: 2.169$ and $\mathrm{S} / \mathrm{P} \%=134.10$ (Positive)

$\mathrm{K}^{*}$ : Kilis, $\mathrm{S}^{*}$ : Shamil.

$\mathrm{A}_{450}$ dalga boyunda Minimum titre $(\mathrm{OD})=0.046$ ve $\mathrm{S} / \mathrm{P} \%=-7.42$ (Negatif)

$\mathrm{A}_{450}$ dalga boyunda Minimum titre $(\mathrm{OD})=2.169$ ve $\mathrm{S} / \mathrm{P} \%=134.10$ (Pozitif)

$\mathrm{K}^{*}$ : Kilis, $\mathrm{H}^{*}$ : Halep.

\section{Discussion and Conclusion}

In the previous studies, ELISA results showing the herd level prevalence of $C$. burnetii infection in goat were ranged from $43 \%$ to almost $100 \%$ (14). Briefly, Q fever prevalence of goat herds determined by ELISA was $13 \%$ in Africa (31), 35\% in Mexico (30), 5.7\% in India (33), 65.8\% in Iran (19). Individual prevalence of $C$. burnetii infection determined in goat by ELISA had been found to be between $5.7 \%$ and $75 \%$ (14). Since 2007 till now, Netherland has experienced human $Q$ fever outbreaks associated with infected goat and sheep farms $(1,27,35)$. A serological survey carried out in sheep and goats in Netherland in 2008, individually, $2.4 \%$ of the sheep and $7.8 \%$ of the goats were determined as antibody positive by ELISA (35). To our knowledge, a total of 10 regional seroprevalence studies conducted on cattle, sheep, goat in Turkey $(3,10,13,16,18,20,22,23,32$, 39). Of them all, solely in two studies, goat sera were examined for the presence of $C$. burnetii antibodies. Payzin et al. (1953) (23), determined 13\% positivity of the examined 278 goat sera by CFT. Arserim et al. (2011) (3) reported that, $270(38.6 \%)$ out of 700 goat sera were found to be positive by an ELISA.

In this study, we decided to determine the prevalence of Q fever in randomly selected, healthy, female, nonpregnant Kilis and Shamil goats, with no clinical signs. We had no knowledge about the tested animals such as any recorded abortion history. Antibody positivity, 7.60\%, $4.34 \%$, and $10.8 \%$ in total 92 goat serum samples, 46 Kilis and 46 Shamil goat serum samples, respectively showed that, those were challenged with $C$. burnetii at any stage of their life. Due to detection capacity of the ELISA kit consisting of phase I, phase II antigens from the Nine Mile Strain of $C$. burnetii, and peroxidase labeled anti- ruminant IgG conjugate, antibodies against both phase I and II could be easily detected, but not discriminated. As the sera were not tested by IFA, the positive antibody titers could not be attributed to an acute infection. However, persisting high level antibodies to phase I and phase II antigens, are thought to be caused by continuous antigenic stimulation and considered indicative for chronic Q fever in humans (37). In contrast to this, the importance of the development of antibody response against phase I and phase II antigens and the stage of the infection has not been well evaluated in animals. In this study, from our point of view, the positive titers cannot be attributed to onset of $\mathrm{Q}$ fever infection. However, the positive ELISA titers were lead us to think that those goats might have been infected with $C$. burnetii at any stage of their life as emphasized above. Serologic tests are not a useful tool to determine which animal represents a current risk for transmission, as animals may seroconvert without shedding or remain positive long after the acute infection. Reichel et al. (25), reported that, in six months 
study, where sampling was scheduled 3 times with 2 months interval from aborted goats, positive antibody ELISA titers had been recorded on the second, even on the third sampling, suggesting a long duration of detectable antibody level. Conversely, some animals may pose a risk for infection prior to development of antibodies by shedding the bacteria and some infected animals never seroconvert (8). In the absence of longitudinal and repeating sampling, seroprevalence studies do not provide information on incidence of current infection in animals, or whether an animal is infectious (30). Hence, the positive ELISA titers were thought to be the evidence of previous infections. Similarly, EFSA stated that individual serology cannot be relied upon to confirm the presence of C. burnetii infection (12). Reichel et al. (25), declared that, positive ELISA results were observed in goats aborted and also in goats without any abortion history. The similar result was also reported by Rousset et al. (27).

When we tested the blood samples of the serologically examined goats for presence of $C$. burnetii DNA by a touchdown-PCR, none of them, gave the expected size of the amplicon, $687 \mathrm{bp}$, showing that the seven antibody positive goats were in the chronic stage of the infection. As previously stated by Musso et al. (21), blood sample was suitable for the peracute stage of the infection in order to detect $C$. burnetii DNA. After primary multiplication in the regional lymph nodes, ensuing bacteraemia lasts for 5-7 days and the organism then localizes in the mammary glands and the placenta of pregnant animals (4). ELISA results were overlapped PCR results, since seroconversion typically occurs 7-15 days after symptoms appear and due to detectable ELISA titers, it was expected not to determine C. burnetii DNAs in the blood samples.

All the tested goats are female. The prevalence rate of Q fever is found to be higher in females than in males since females are more susceptible to $\mathrm{Q}$ fever than males. In addition, hormonal changes during pregnancy results with the increased multiplication of $C$. burnetii in the placenta (24). Yet, we had no knowledge about goat's history. Anyway we could say, due to the gender of examined goats, those might have been prone to $\mathrm{Q}$ fever.

The geography, landscape and climate may also play a role in the spread of infection (36). The geographical features of Kilis is mountainous bordering to Syria and semi-mountainous in its vicinity with specific climatic conditions, varying from tropical-humid to hot-dry. The climate of Kilis can be termed as intersection point of Mediterranean and continental climates. Either geographical characteristics or climatic features of the province are appropriate for the dispersion of aerosols via air. The economy of Kilis depends on agriculture and animal husbandry. Prevalence of $Q$ fever in Shamil and Kilis goats were related to geographical variation, climatic conditions and economy of this region. Due to economic status in South-Eastern Anatolian Region of Turkey could lead inadequate animal husbandry conditions which might result in spreading various agents in the flocks, as previously stated by Cetinkaya et al. (10) and Arserim et al. (3).

Consequently, seropositivity in goats had a ratio that should not be ignored in the province of Kilis. Either geographical or climatic features of the province prone the animals to $\mathrm{Q}$ fever, therefore, veterinary authorities should take prompt preventive measures and raise awareness of animal breeders to take hygienic measures in order to restrict the probable infection.

\section{References}

1. Angelakis E. and Raoult D. (2010): Q Fever. Vet Microbiol, 140: 297-309.

2. Arricau-Bouvery N., Souriau A., Lechopier P. and Rodolakis A. (2003): Experimental Coxiella burnetii infection in pregnant goats: excretion routes. Vet Res, 34: 423-33.

3. Arserim N.B., Yesilmen S., Tel O.Y., Ozakinci T., Keskin O., Pulat H., and Vural A. (2011): Seroprevalance of Coxiellosis in cows, sheep, goats and humans in Diyarbakir region of Turkey. Afr J Microbiol Res, 5: 20412043.

4. Babudieri B. (1959): $Q$ fever: a zoonosis. Adv Vet Sci Comp Med, 5: 82-154.

5. Berri M., Rousset E., Champion J.L., Arricau-Bouvery N., Russo P., Pepin M. and Rodolakıs A. (2003): Ovine manure used as a garden fertiliser as a suspected source of human $Q$ fever. Vet Rec, 153: 269-270,

6. Berri M., Rousset E., Champion J.L., Russo P. and Rodolakis A. (2007): Goats may experience reproductive failures and shed Coxiella burnetii at two successive parturitions after a $Q$ fever infection. Res Vet Sci, 83: 4752.

7. Berri M., Rousset E., Hechard C., Champion J., Dufour P., Russo P., Rodolakis A. (2005): Progression of $Q$ fever and Coxiella burnetii shedding in milk after an outbreak of enzootic abortion in a goat herd. Vet Rec, 156: 548-549,.

8. Berri M., Souriau A., Crosby M., Crochet D., Lechopier P. and Rodolakis A. (2001): Relationships between the shedding of Coxiella burnetii, clinical signs and serological responses of 34 sheep. Vet Rec, 148: 502505.

9. Bjorka A. And Anderson A. (2011): Notes from the field: $Q$ fever outbreak associated with goat farms - Washington and Montana, 2011. CDC MMWR. 60:1393-94.

10. 10.Cetinkaya B., Ertas H.B., Muz A., Ongor H., Kalender H., Arslan N. and Gurcay M. (2000): Seroprevalence of coxiellosis in cattle, sheep and people in the east of Turkey. Vet Rec, 146: 131-136,.

11. Dogru A., Yildirim M., Unal N. and Gazyagei S. (2010): The relationship of Coxiella burnetii seropositivity between farm animals and their owners: A pilot study. J Anim Vet Adv, 9: 1625-1629.

12. EFSA PANEL on Animal Health and Welfare (AHAW) (2010). Scientific Opinion on Q fever. EFSA J, 8: 1595,. 
13. Gazyagci S., Aktas M.S., Kilic S., Babur C., Celebi B. and Duru S.Y. (2011): Seroprevalence of $Q$ fever in dairy cattle in the Konya province, Turkey. Revue Méd Vét, 162: 387-390.

14. Guatteo R., Seegers H., Taurel A.F., Joly A. and Beaudeau F. (2011.): Prevalence of Coxiella burnetii infection in domestic ruminants: a critical review. Vet Microbiol, 149: 1-16,

15. Hoover T.A., Vodkin M.H. and Williams J.C. (1992): $A$ Coxiella burnetti repeated DNA element resembling a bacterial insertion sequence. J Bacteriol, 174: 5540-5548.

16. Kalender H. (2001): The incidence of Coxiella burnetii infection in ewes in Elazig and neighboring provinces. Turk J Vet Anim Sci, 25: 51-55.

17. Kampschreur L.M., Oosterheert J.J., Koop A.M., Wegdam-Blans M.C., Delsing C.E., Bleeker-Rovers C.P., De Jager-Leclercq M.G., Groot C.A., Sprong T., Nabuurs-Franssen M.H., Renders N.H., Van Kasteren M.E., Soethoudt Y., Blank S.N., Pronk M.J., Groenwold R.H., Hoepelman A.I. and Wever P.C. (2012): Microbiological challenges in the diagnosis of chronic $Q$ fever. Clin. Vaccine Immunol, 19: 787-90.

18. Kennerman E., Rousset E., Golcu E. and Dufour P. (2010): Seroprevalence of $Q$ fever (coxiellosis) in sheep from the Southern Marmara Region, Turkey. Comp Immunol Microbiol Infect Dis, 33: 37-45.

19. Khalili M. and Sakhaee E. (2009): An update on a serologic survey of $q$ fever in domestic animals in Iran. Am J Trop Med Hyg, 80: 1031-1032.

20. Kilic S., Pasa S., Babur C. and Ozlem M.B. (2005): Investigation of Coxiella burnetii antibodies in sheep in Aydin region, Turkey. Revue Méd Vét, 156: 336-340.

21. Musso D. and Raoult D. (1995): Coxiella burnetii blood cultures from acute and chronic Q-fever patients. J Clin Microbiol, 33: 3129-3132.

22. Ozdemir, H., Can R., Sezen I.Y., Gulcu H.B., Kalender H. and Basbug O. (1999): Prevalence of $Q$ fever in sheep in Elazig province and its treatment. Firat Univ J Health Sci, 13: 143-149.

23. Payzin S. (1953): Epidemiological investigations on $Q$ fever in Turkey. Bull. Org. Mond. Sante Bull. Wort Health Org, 9: 553-558.

24. Porter R.S., Czaplicki G., Mainil J., Guatt'Eo R. and Saegerman C. (2011): Q Fever: Current state of knowledge and perspectives of research of a neglected zoonosis. Int $\mathrm{J}$ of Microbiol Article ID 248418, doi:10.1155/2011/248418.

25. Reichel R., Mearns R., Brunton L., Jones R., Horigan M., Vipond R., Vincent G. and Evans S. (2012): Description of a Coxiella burnetii abortion outbreak in a dairy goat herd, and associated serology, PCR and genotyping results. Res Vet Sci, 93: 1217-1224.

26. Rodolakis A. (2006): Q fever, state of art: epidemiology, diagnosis and prophylaxis. Small Ruminant Res, 62:121124.

27. Roest H.I., Tilburg J.J., Van Der Hoek W., Vellema P., Van Zijderveld F.G., Klaassen C.H. and Raoult D. (2011): The $Q$ fever epidemic in the Netherlands: history, onset, response and reflection. Epidemiol Infect, 139: 112.
28. Rousset E., Berri M., Durand B., Dufour P., Prigent M.Y.R., Delcroix T., Touratier A. and Rodolakis A. (2009): Coxiella burnetii shedding routes and antibody response after outbreaks of $q$ fever-induced abortion in dairy goat herds. Appl Environ Microbiol, 75: 428-433.

29. Rousset, E., Durand B., Berri M., Dufour P., Prigent M., Russo P., Delcroix T., Touratier A., Rodolakis A. and Aubert M. (2007): Comparative diagnostic potential of three serological tests for abortive $Q$ fever in goat herds. Vet Microbiol, 124: 286-297.

30. Salinas-Melédez J.A., Avalos-Ramirez R., RiojasValdez V., Kawas-Garza J., Fimbres-Durazo H. and Hernández-Vidal G. (2002): Serologic survey in animals of ' $Q$ ' fever in Nuevo Leon. Rev Latinoam Microbiol, 44 : 75-78.

31. Schelling E., Diguimbaye C., Daoud S., Nicolet J., Boerlin P., Tanner M. and Zinsstag J. (2003): Brucellosis and Q-fever seroprevalences of nomadic pastoralists and their livestock in Chad. Prev Vet Med, 61: 279-93.

32. Seyitoglu S., Ozkurt Z., Dinler U. and Okumus B. (2006): The seroprevalence of coxiellosis in farmers and cattle in Erzurum district in Turkey. Turk J Vet Anim Sci, 30: 71-75.

33. Vaidya V.M., Malik S.V., Bhilegaonkar K.N., Rathore R.S., Kaur S. and Barbuddhe S.B. (2010): Prevalence of $Q$ fever in domestic animals with reproductive disorders. Comp Immunol Microbiol Infect Dis, 33: 307-21.

34. Vaidya V.M., Malik S.V.S., Kaur S., Kumar S. and Barbuddhe S.B. (2008): Comparison of pcr, immunofluorescence assay, and pathogen isolation for diagnosis of $Q$ fever in humans with spontaneous abortions. J Clin Microbiol, 46: 2038-2044.

35. Van Den Brom R., Moll L., Van Schark G. and Vellema P. (2013): Demography of $Q$ fever seroprevalence in sheep and goats in the Netherland in 2008. Prev Vet Med, 109: 76-82.

36. Van Der Hoek W., Hunink J., Vellema P., Droogers P. (2011): $Q$ fever in the Netherlands: the role of local environmental conditions. Int J Environ Health Res, 21: 441-51.

37. Wegdam-Blans M.C.A., Ter Woorst J.F., Klompenhouwer E.G. and Teijink J.A. (2012): David procedure during a reoperation for ongoing chronic $Q$ fever infection of an ascending aortic prosthesis. Eur J Cardiothorac Surg, 1-2, doi:10.1093/ejcts/ezs217.

38. Woldehıwet Z. (2004): Q fever (coxiellosis): Epidemiology and pathogenesis. Res Vet Sci, 77: 93-100.

39. Yurtalan S. (2003): Seroprevalence of Coxiella burnetii ( $Q$ fever) infection in cattle in Marmara Region. J Pendik Vet Microbiol, 34: 41-49.

Geliş tarihi: 04.11.2013 / Kabul tarihi: 26.02.2014

Address for correspondence:

Dr. Elçin Günaydın

Veterinary Control Central Research Institute,

Breeding Disease Laboratory,

Etlik, Ankara, TURKEY.

e-mail:elcin_gunaydin@hotmail.com 